\title{
Correction to: Grip strength from midlife as an indicator of later-life brain health and cognition: evidence from a British birth cohort
}

Quentin Dercon ${ }^{1 *}$, Jennifer M. Nicholas ${ }^{2}$, Sarah-Naomi James ${ }^{3}$, Jonathan M. Schott ${ }^{4}$ and Marcus Richards ${ }^{3}$

\author{
Correction to: BMC Geriatr 21, 475 (2021) \\ https://doi.org/10.1186/s12877-021-02411-7
}

After publication of this article [1], the authors noticed 3 empty cells in Table 1 , whereas they should read " $<0.001$ ".

The original article [1] has been updated.

\begin{abstract}
Author details
${ }^{1}$ MRC Cognition and Brain Sciences Unit, University of Cambridge, Cambridge, United Kingdom. ${ }^{2}$ Department of Medical Statistics, London School of Hygiene \& Tropical Medicine, London, United Kingdom. ${ }^{3}$ MRC Unit for Lifelong Health and Ageing at UCL, University College London, London, United Kingdom. ${ }^{4}$ Dementia Research Centre, UCL Queen Square Institute of Neurology, University College London, London, United Kingdom.
\end{abstract}

Published online: 29 September 2021

\section{Reference}

1. Dercon Q, Nicholas JM, James SN, Schott JM, Richards M. Grip strength from midlife as an indicator of later-life brain health and cognition: evidence from a British birth cohort. BMC Geriatr. 2021;21:475 https://doi.org/10.1186/ s12877-021-02411-7.

The original article can be found online at https://doi.org/10.1186/s12877021-02411-7.

*Correspondence: quentin.dercon@mrc-cbu.cam.ac.uk

'MRC Cognition and Brain Sciences Unit, University of Cambridge, Cambridge, United Kingdom

Full list of author information is available at the end of the article

(c) The Author(s). 2021 Open Access This article is licensed under a Creative Commons Attribution 4.0 International License, which permits use, sharing, adaptation, distribution and reproduction in any medium or format, as long as you give appropriate credit to the original author(s) and the source, provide a link to the Creative Commons licence, and indicate if changes were made. The images or other third party material in this article are included in the article's Creative Commons licence, unless indicated otherwise in a credit line to the material. If material is not included in the article's Creative Commons licence and your intended use is not permitted by statutory regulation or exceeds the permitted use, you will need to obtain permission directly from the copyright holder. To view a copy of this licence, visit http://creativecommons.org/licenses/by/4.0/ The Creative Commons Public Domain Dedication waiver (http://creativecommons.org/publicdomain/zero/1.0/) applies to the data made available in this article, unless otherwise stated in a credit line to the data. 